\title{
ENGELS: o interlocutor fundamental de Marx
}

\author{
HUNT, Tristram. Comunista de casaca: a vida revolucionária de Friedrich \\ Engels. Traduzido por: Dinah Azevedo. Rio de Janeiro: Record, 2010 (472p).
}

\section{Jéferson Dantas*}

O historiador britânico Tristram Julian William Hunt (1974-), ao traçar a biografia do parceiro intelectual de Karl Marx (1818-1883), Friedrich Engels (1820-1895), poderia ter optado por um ensaio truanesco, tão ao gosto de determinada mídia mais preocupada com adjetivismos e juízos de valor, do que propriamente com a contribuição filosófica de seu retratado. Foi, justamente, a partir da leitura enviesada da obra de Hunt por setores da mídia impressa, que procurei trazer à tona a contribuição deste professor de História da Universidade de Londres e comentarista político nos jornais The Guardian, The Times e London Review Of Books.

De fato, Hunt explora em várias passagens de seu texto a personalidade e a vida privada de Engels, desmitificando sua persona vetusta e austera. Engels é apresentado como um 'homem de ação vitoriano', sedento por novos conhecimentos, porém, que não desprezava o 'mergulho nos prazeres carnais de Paris'; um 'dom-juan experiente', cuja boa aparência e ‘comportamento devasso granjeavam-lhe muitas amantes'. E mais adiante, Hunt vaticina: "Impressionante é o fato de Engels ter conseguido fazer política enquanto andava atrás de um rabo de saia” (HUNT, 2010, p. 164). Afastadas essas observações que poderiam tornar a obra do historiador inglês um conjunto de anedotas, a principal tese do livro é demonstrar as contradições ou a ‘vida dupla’ de Engels:

\footnotetext{
* Bacharel e Licenciado em História, Mestre em Educação e Doutorando no Programa de Pós-Graduação em Educação no Centro de Ciências da Educação da Universidade Federal de Santa Catarina. E-mail: clioinsone@gmail.com
} 
[...] de dia era um respeitável barão algodoeiro, um membro de casaca da classe média alta; à noite, o socialista revolucionário, um discípulo fervoroso das classes menos favorecidas. Para manter o emprego no escritório, sustentar Marx e manter a causa comunista à tona, Engels foi obrigado a manter uma fachada de penoso decoro. O esforço de viver em dois mundos era desgastante, e a contradição entre as declarações públicas e as crenças pessoais acabam lançando Engels num espiral de doença, depressão e colapso nervoso (Idem, p. 229).

Assim, 'a ambição de Tristram Hunt' é captar as paixões, as aversões pessoais e os caprichos individuais de um homem corresponsável por um dos mais importantes tratados filosóficos a que a humanidade já teve acesso. Não me refiro apenas à obra $O$ capital, em que ele foi interlocutor basilar, por meio de extensa correspondência com Marx, mas de obras seminais, que contribuíram decisivamente para a sua compreensão da Inglaterra industrial e dos mecanismos da lógica capitalista, sendo a primeira delas A situação da classe trabalhadora na Inglaterra (1845), um texto juvenil voluntarioso, mas empiricamente detalhista.

Fortemente influenciado pelo Romantismo alemão e um leitor atento de Hegel, Friedrich Engels procurou, ao longo de sua existência, compreender as questões familiares, as teorias de cunho militar, a libertação sexual feminina e a insurgência dos países colonizados, algo pelo qual Marx nunca teria se aventurado com denodo, teoricamente. Diante da teologia especulativa hegeliana (um mundo desencarnado e não terreno), Engels passou a se dedicar com mais afinco, no final da segunda metade do século XIX, aos estudos da realidade econômica, período que teria conhecido Karl Marx, e estabelecido, com ele, uma relação fecunda e íntima. A afinidade entre Engels e Marx extrapolou os limites acadêmicos, a ponto de Engels ter cuidado das filhas de Marx como se fosse um parente próximo, afeto reciprocamente recompensado pelas filhas do 'mouro' (apelido de Marx). O investimento de Engels em Marx (literalmente falando) tinha a sua razão de ser pelo primeiro acreditar que Marx era um gênio, e ele apenas um pensador talentoso. Engels afirmava enfaticamente que sem Marx, o materialismo histórico dialético não existiria.

Mesmo após Marx ter tido um filho fora do casamento e, de certo modo, rejeitado a criança, Engels assumiu a paternidade oficial do filho do amigo para protegê-lo de escândalos públicos. Aqui, Hunt dedica boas páginas ao envolvimento de Marx com a sua empregada e aos 'dramas de alcova folhetinescos' bem ao gosto de um público sedento por narrativas burlescas. Mas, Tristram Hunt, quando consegue se desvencilhar da historieta bufônica, atinge pontos altos em sua descrição biográfica de Engels, principalmente porque está 
fundamentado em vasta bibliografia e fontes de primeira mão. Esta é a grande contribuição do historiador inglês: desvelar a extensa troca de missivas entre Engels e Marx (por meio das quais é possível se perceber que a obra $O$ capital foi uma tarefa realizada a quatro mãos) e expor a 'humanidade' desses destes homens, equivocadamente mitificados e extremamente vigilantes, em relação aos fenômenos históricos de seu tempo.

Segundo Hunt, o desaparecimento de Marx em 1883 não só levou o melhor amigo de Engels, mas a 'maior parceria intelectual da filosofia do ocidente'. Após a morte do amigo, Engels procurou defender a sua memória, principalmente de seus desafetos e detratores, que vulgarizaram o socialismo científico. Friedrich Engels se tornou o 'curador da obra marxiana', ao mesmo tempo que passou a se dedicar a novos escritos, notadamente em relação aos efeitos nefastos do patriarcado nas chamadas famílias modernas, de onde se originou o livro A origem da família, da propriedade privada e do Estado (1884). Além disso, com todos os limites aí postos, Engels angariou a admiração das feministas da década de 1970 ao tratar as questões de gênero pela ótica econômico-produtiva e não pelo 'determinismo biológico’. Seus últimos anos de vida foram dedicados a promover a causa marxista, através da publicação dos últimos volumes de $O$ capital. Engels procurou, até o último suspiro, evitar o dogma e o clichê para popularizar o legado de Marx, e que a 'intervenção política não poderia ser exageradamente prescritiva e nem inutilmente vaga'. Finalmente, veio a falecer no dia 5 de agosto de 1895.

Tristram Hunt procura isentar Engels das acusações que recebeu após a sua morte, principalmente de ter sido o mentor do socialismo soviético controlado por Stalin, quando o socialismo científico foi transformado numa ortodoxia rígida e que "contaminou praticamente todos os elementos da vida cultural, científica, política e privada” (Idem, p. 399) da extinta União Soviética. Nesta direção, o historiador britânico destaca que não se pode culpar Engels ou Marx pelos crimes cometidos por agentes históricos gerações depois, mesmo que as políticas de Estado tenham sido realizadas em seus nomes; assim como não se pode julgar Adam Smith pela desregulamentação do mercado ou Maomé pelas atrocidades de Osama Bin Laden.

Opiniões à parte, Hunt procurou desenvolver uma síntese da trajetória existencial, intelectual e política do teórico alemão Friedrich Engels, e contextualizou os momentos mais marcantes de sua juventude e da convivência com Marx, iniciada quando os dois tinham pouco mais de vinte anos de idade. Esta relação de amizade duradoura e os reflexos da interlocução permanente denotaram extrema vigilância epistemológica, fizeram destes homens figuras centrais de um método de apreensão da realidade social que, se por um lado 
pode ser ignorado atualmente pela desrazão pós-moderna, certamente não pode ser desprezado pelas ciências humanas até os dias de hoje. 